\title{
Lara - Kundu (Antalya) Düzlüğünün Sıvılaşma Şiddeti İndeksi’ne (LSI) Dayalı Sıvılaşma Haritası
}

\author{
Liquefaction Severity Index (LSI) - Based Liquefactıon Map of the Lara - Kundu Plain \\ (Antalya)
}

Nihat DIPOVA, Bülent CANGír

Akdeniz Üniversitesi, İnşaat Mühendisliği Bölümü, Kampüs, ANTALYA

Geliş (Received): 02 Ağustos (August) 2016 / Düzeltme (Revised): 09 Aralık (December) 2016 / Kabul (Accepted): 27 Ocak (January) 2017

\section{ÖZ}

$\mathrm{Bu}$ çalışmada Antalya Lara-Kundu kıyı alanındaki zeminlerin mühendislik özellikleri ve bölgedeki kumlu zeminlerin sıvılaşma potansiyeli incelenmiştir. Bu amaçla, her biri 20 metre derinliğinde 20 adet sondaj kuyusu açılarak her 1.5 m'de bir numune alınmış, zeminin fiziksel ve mekanik özellikleri laboratuvarda belirlenmiştir. Arazide SPT ve CPT deneyleri yapılmıştır. Bölgede hakim zemin cinsi sıkı kum olmakla birlikte bazı bölümlerde gevşek kum, kil ve turba da bulunmaktadır. Sismik tehlike analizi yapılarak maksimum yer ivmesi haritası elde edilmiştir. Zemin profilindeki kum katmanlarının sıvılaşma potansiyeli, olasılıksal sıvılaşma potansiyeli analizi ile araştırılmıştır. Bir inceleme noktasındaki tüm katmanlar için belirlenen olasılıksal sıvılaşma potansiyeli değerleri (PL) kullanılarak sıvılaşma şiddeti indeksi (LSI) değerleri elde edilmiştir. Elde edilen tüm veriler ışığında coğrafi bilgi sistemleri (CBS) kullanılarak zemin sıvılaşma şiddeti indeksi (LSI) haritası oluşturulmuştur.

Anahtar Kelimeler: CBS, CPT, Lara-Kundu, LSI, Sıvılaşma, SPT.

\section{ABSTRACT}

In this research, engineering properties of Lara-Kundu coastal plain soils and liquefaction potential of the sands in the region have been investigated. For this purpose, samples which were taken at an interval of $1.5 \mathrm{~m}$ from 20 boreholes of $20 \mathrm{~m}$ depth, were investigated in the laboratory, and soil index, strength and compressibility properties were determined. In situ tests which are SPT and CPT were executed. Dense sand is the main soil type of the region, and also in some parts loose sand, clay and peat are also available. Carrying out seismic hazard analysis, a peak ground acceleration contour map has been generated. Probabilistic liquefaction potential analysis was performed to search for liquefaction potential of sand layers in the soil profile. LSI (Liquefaction Severity Index) value was calculated with the help of PL values which were determined for every depth of the searching location. By using all the data and Geographical Information Systems (GIS) technique; liquefaction severity index (LSI) map of the soils of Lara - Kundu Region has been created.

Keywords: GIS, CPT, Lara-Kundu, LSI, Liquefaction, SPT. 
Dipova, Cangir

\section{GÍRIŞ}

Depremin oluşturduğu tekrarlı yüklerin etkisiyle gevşek, suya doygun durumdaki daneli zeminlerin taşıma güçlerini kaybederek sıvı gibi davranış göstermesine, "zemin sıvılaşması" denilmektedir. Suya doygun gevşek kum/kumlu zeminler, tekrarlı yükler altında sıkışma ve hacim daralması eğilimi gösterirler. Bu durum, drenajın olmadığı koşullarda boşluk suyu basıncını artırır. Toplam normal gerilme boşluk suyu basıncına eşit değere ulaşır ve kohezyonsuz zemin bir sıvı gibi davranarak büyük yer değiştirmelere maruz kalır (Das, 1983). Genellikle jeolojik olarak genç ve gevşek çökellerin, özellikle kum ve silt tane boyutundaki malzemenin depolandığ ve yeraltı suyu seviyesinin sığ olduğu ortamlar, sıvılaşmanın gelişmesi için en uygun ortamlardır. Sıvılaşma olayı, pek çok depremde gelişmesine karşın, ülkemizde 1992 Erzincan depremiyle dikkate alınmaya başlanmış, 1999 Marmara depreminde meydana gelen sıvılaşma olayları ile de önem kazanmıştır.

$\mathrm{Bu}$ çalışmaya konu olan Lara-Kundu kıyı alan1, Antalya-Alanya karayolunun güneyinde, Lara ve Kundu Kumsalı'nın, turistik otellerin, alışveriş merkezlerinin ve konutların bulunduğu yaklaşık $15 \mathrm{~km}^{2}$ lik bir alanı kapsamaktadır. Bölge 90'l1 yıllara kadar tarımsal ve doğal alan özelliğini korumuş, ancak bundan sonra yapılaşmaya açılmıştır. 2010'lu yıllarda özellikle kıyı şeridinde inşaat faaliyetleri hızlanmış ve günümüzde sahil şeridi neredeyse tümüyle yapılaşmıştır. Alandaki yapılarda aşırı oturma ve farklı oturma (eğilme) sorunlarına sıç̧a rastlanmaktadır. Bunun yanı sıra bölgede suya doygun halde bulunan gevşek kum tabakalarının sıvılaşma potansiyeli de merak konusu olmuştur. Yüzeydeki gevşek kumulların varlığından hareketle bölgede sıvılaşma potansiyelinin yüksek olduğu kanısı yaygın hale gelmiştir.
Çalışma alanının sınırları belirlenirken batı ve kuzey batıdaki kayalıklar, diğer kısımlarda ise imar alanı sınırı dikkate alınmıştır.

Literatürde Antalya bölgesinin depremselliği ve sıvılaşma riskinin belirlenmesi için sınırlı sayıda çalışma bulunmaktadır. Acar ve Budak (2004) yaptıkları çalışmada Antalya bölgesinde oluşabilecek deprem riski analizinde bölgenin tamamını tek bir alan kaynak olarak dikkate almıştır. Dipova ve Cangir (2011), belirlenen kaynak bölgelerine göre deterministlik olarak deprem tehlike analizlerini gerçekleştirirken, Deniz ve Yücemen (2005), yaptıkları olasılıksal deprem tehlike hesabi sirasinda Antalya yöresi için Bommer vd. (2002) tarafindan önerilen kaynak bölgelerini temel almıştır. Bu çalışmalar dikkate alındığında bölge için yapılan hesaplamalarda kullanılan azalım ilişkilerinin, deprem üretebilecek kaynak bölgelerin farklığından dolayı, güncel azalım ilişkisi ve sismik kaynak bölgelemesi kullanılarak bir deprem tehlike analizi yapılması ve sıvılaşma analizleri için gerekli olan en büyük deprem ivmesi $\left(\mathrm{a}_{\text {maks }}\right)$ belirlenmesinin gerekli olduğu anlaşılmaktadır.

$\mathrm{Bu}$ çalışmada, çalışma alanının hakim zeminleri olan kum, kil ve organik kökenli (turba) zeminlerin indeks, dayanım ve sıkışabilirlik özellikleri laboratuvar ve arazi deneyleri ile incelenmiştir. Ayrıca, güncel sismik kaynak bölgelemesi kullanılarak, deprem tehlike analizi yapılmış ve sıvılaşma analizleri için gerekli olan parametrelerden olan $a_{\text {maks }}$ elde edilmiştir. Arazi ve laboratuvar deney sonuçları kullanılarak bölgede bulunan suya doygun kum zeminlerin sıvılaşma potansiyeli araştırılmıştır. Coğrafi bilgi sistemleri (CBS) tabanlı bir bilgisayar yazılımı olan ArcGIS r.9.3 (ESRI, 2009) kullanilarak veri tabanındaki tüm veriler, sayısal haritalar ve sondaj noktaları birlikte değerlendirilerek 
çalışılan bölgelerin sıvılaşma potansiyeli araştırılmış ve zemin sıvılaşma şiddeti indeksi (LSI) haritası oluşturulmuştur. Depreme bağlı olarak denize doğru gelişebilecek olası yanal yayılma türü sıvılaşmaya bağlı zemin hareketleri ve olas1 deniz alt1 heyelanlar1 gibi olgular bu çalışmanın kapsamı dışında tutulmuştur.

\section{JEOLOJIK VE JEOMORFOLOJIKK ÖZELLİKLER}

Kıyı alanının batısı ve kuzeyi yer yer 40 $m$ yüksekliği bulan falez niteliğinde olan tufa kayalıkları ile çevrilidir. Kıyı alanının doğu komşusu ise Belek kıyı alanı ve Aksu Ovası'nın doğu bölümüdür (Şekil 1). Alanın güneyi Akdeniz ile sınırlıdır. Alanın imara açık bölümleri ve tarım alanı olarak kullanılan kesimlerinde kot denizden ortalama 3 m yüksekliktedir. Kıyı kumullarında ise yükseklik 15 m'ye kadar ulaşmaktadır (Dipova ve Oğuz, 1998). Yeraltı suyu seviyesi sığ olup derinlik 1 m’ye kadar düşmektedir.
Lara-Kundu kıyı alanı zeminleri, Aksu ve Köprüçay akarsularının taşıdığı sedimanlarla oluşmuştur. $\mathrm{Bu}$ mekanizma içinde ince taneli malzemeler denize kadar taşınarak Lara kıyı şeridini oluşturmuştur. Düşük eğimli taban topoğrafyası ve denizden esen hakim rüzgarlar sonucu "kıyı kumul"u oluşmaya başlamıştır (Dipova, 2002). Çeşitli jeolojik evrelerde taşınan malzemede kil ve silt içeriği arttı̆̆ında ya da gölsel ve bataklıksal çökelim söz konusu olduğunda kum içinde kil, silt ve turba katman yada mercekleri gözlenebilmektedir. Kıy1 kumullarının oluşturduğu bariyer arkasında lagün oluşmuştur (Yamansaz sulak alanı). Antalya ve çevresinde yürütülen bataklık kurutma çalışmaları kapsamında bu alanda da kanallar açılarak Yamansaz'ın bir kısmı kurutulmuştur. Sulak alanın kuruması sonucu ortaya "turba" sınıfı bir zemin ortaya çıkmıştır.

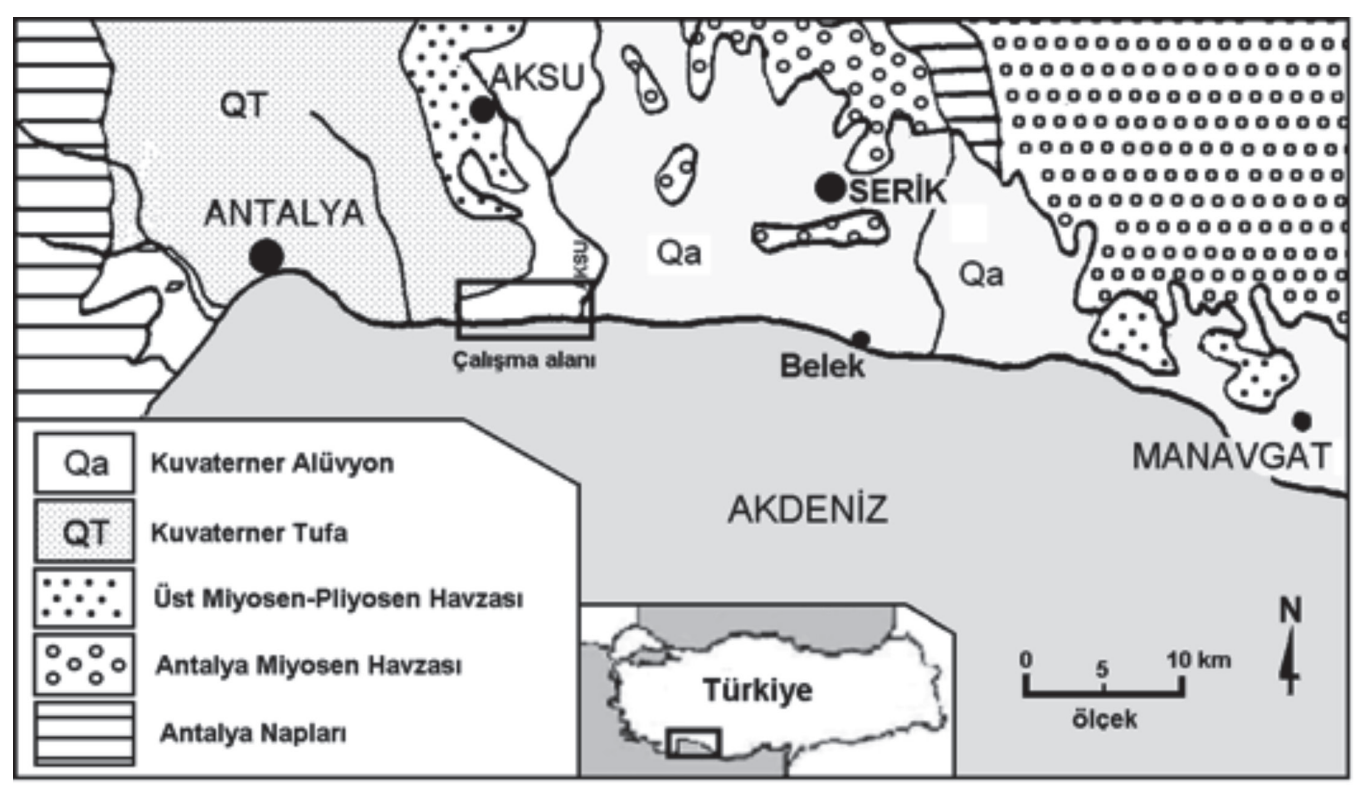

Şekil 1. İnceleme alanının jeoloji haritası (Akay vd., 1985'ten değiştirilerek).

Figure 1. Geological map of the study area (modified from Akay et al., 1985). 


\section{ARAZI VE LABORATUVAR ÇALIŞMALARI}

Antalya'daki yerel yönetim ve proje bürolarının arşivleri taranarak çalışma alanında daha önceden yapılmış zemin etüdü çalışmaları temin edilmiş ve değerlendirilmiştir. $\mathrm{Bu}$ kaynaklardan akademik düzeyde nitelikli veri sağlanamadığ 1 için araştırmaya özgü veriler üretmek amacıyla arazi programı başlatılmıştır. Arazi çalışmaları kapsamında 20 adet 20 metre derinliğinde sondaj kuyuları açılarak her 1.5 m'de bir alınan numuneler laboratuvarda incelenmiş, zeminin fiziksel ve mekanik özellikleri belirlenmiştir. Sondajlar sırasında $1.5 \mathrm{~m}$ 'de SPT (Standart Penetrasyon Deneyi) yapılmıştır. Kum, kil, turba türü zeminlerden oluşan zeminde sondaj kuyusunun göçmemesi, örselenmenin en aza indirilmesi ve iş veriminin artırılması amaciyla içi boş burgu (hollow stem auger) sistemi kullanılmıştır (Şekil 2A). Bölgede yapılan sondajlarda kaynama problemi bilindiğinden sondaj takımının iç boşluğu su ile dolu tutularak ilerleme yapılmıştır. Örselenmemiş örnek alımı ve SPT deneyleri takım yukarı çekilmeden kanatlı kısmın ortasındaki boşlukta gerçekleştirilmiştir.
10 ayrı lokasyonda CPT (Koni Penetrasyon Deneyi) gerçekleştirilmiştir. Kamyon üzerine monteli, Hogentogler marka CPT ve boşluk suyu basıncı (CPT-U) ölçme donanımına sahip tam otomatik CPT makinesi (Şekil 2B) kullanılarak uç direnci, çevre sürtünmesi ve boşluk suyu basıncı değerleri ölçülmüştür. Statik sondalama ile CPT penetrometresi ortalama $2 \mathrm{~cm} / \mathrm{sn}$ hızla zemine itilmektedir. Penetrometre, konik uçlu, uç açısı $60^{\circ}$, çap1 $35.5 \mathrm{~mm}$, sürtünme çevre yüksekliği $134 \mathrm{~mm}$ olan direnç ölçerdir. Zemin uç direnci $\left(q_{c}\right) 1000$ mm² $^{2}$ lik uç alanında, çevre sürtünmesi direnci (f) $15000 \mathrm{~mm}^{2}$ ' lik yanal yüzeyde ölçülür. Uç direnci değerleri itme sırasında oluşan boşluk suyu basıncına göre düzeltme işlemine tabi tutulmuş ve düzeltilmiş uç direnci $\left(\mathrm{Q}_{\mathrm{t}}\right)$ değerleri elde edilmiştir. Çalışmanın başında SPT ve CPT verilerinin birlikte değerlendirilmesi düşünülmüş olmakla birlikte, zemin profilindeki iri daneli ve s1k1 seviyeler CPT probunun istenilen derinliklere ulaşmasına izin vermemiştir. $\mathrm{Bu}$ nedenle $\mathrm{CPT}$ verileri çalışmaya ait veriler olarak sunulmuş olmasına rağmen sıvılaşma analizlerinde kullanılmamış, aynı lokasyonlarda ilave sondaj ve SPT deneyi yapılmıştır.

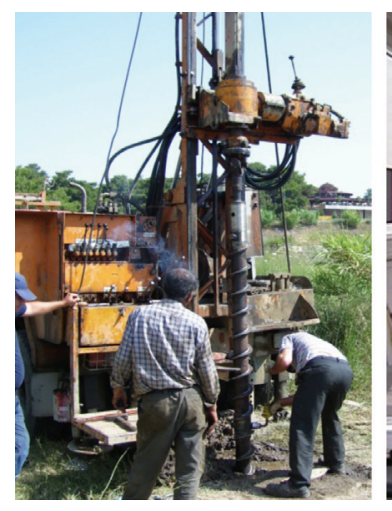

(A)

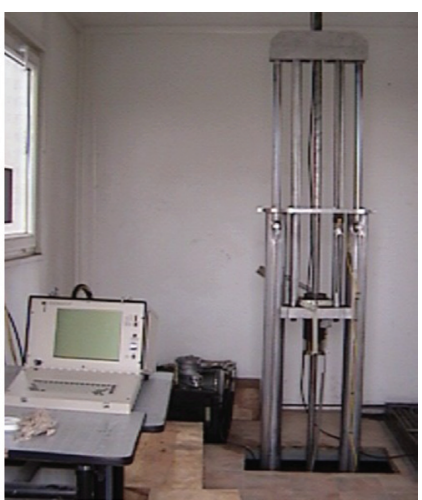

(B)

Şekil 2. A) İçi boş burgu takımlı hidrolik sondaj makinesi ile delgi işlemi, B) Boşluk suyu basıncı (CPT-U) ölçme donanımına sahip CPT makinesi kullanılarak statik sondalama.

Figure 2. A) Drilling operation with hydraulic drilling rig and hollow stem augers, B) Static probing using CPT machine and pore pressure equipment (CPT-U). 
Sondaj ve CPT lokasyonları Şekil 3'te, sondaj bilgilerinden elde edilen A-B zemin kesiti ise Şekil 4'te verilmiştir. Arazi çalışmaları kapsaminda yapılan SPT ve CPT deneylerinin sonuçları sırasıyla Şekil 5 ve 6'da verilmektedir.

Tüm sondaj kuyularında elde edilen örselenmiş numuneler üzerinde yapılan dane boyu dağ 1 lımı analizi sonuçlarına göre bölgedeki hakim zemin cinsinin siltli kum (SM) ve kötü derecelenmiş kum (SP) olduğu görülmüştür. Yapılan hidrometre deney sonuçlarına göre ise SP ve SW karakterli kumların ince tane oranının \% 5 - \% 12 arasında değiştiği ve ince maddenin çoğunlukla silt (M) olduğu, böylece de hakim zemin cinsinin SP-SM veya SW-SM olduğu sonucuna ulaşılmıştır. Kum zeminlerin kum, çakıl ve ince dane yüzdeleri Şekil 7A'da sunulmaktadir.

Zemin sıvılaşma araştırmalarının ilk adımı zemin profilinde potansiyel olarak sıvılaşacak zemin katmanlarının bulunup bulunmadığının belirlenmesidir. "Temiz kum" olarak nitelendirilen üniform kumların potansiyel olarak sıvılaşabilirliği genel kabul görmüş olmasına rağmen siltli kumlar ve çakıllı zeminlerin sıvılaşabilirliği konusunda halen bir uzlaşma sağlanamamıştır. Tsuchida (1970) literatürdeki sıvılaşmış kumların tane boyu dağılımlarını inceleyerek zemin sıvılaşmasına etkisini araştırmış ve dağılım sınırlarını belirlemiştir. Buna göre, üniform kumlar iyi derecelenmiş kumlara kıyasla, ince kumlar ise iri taneli kumlara kıyasla daha kolay sıvılaştırılabilir. İnceleme alanındaki 20 sondaj kuyusuna ait 227 adet tane boyu dağılımı grafiği Şekil 7B'de sunulmuştur. Zeminler çoğunlukla "olası sıvılaşabilir" bölgede, kısmen de "sıvılaşabilir" bölgede yer almaktadır.

Her ne kadar yaygın zemin türü kum, çakıllı kum, sillti-killi kum olsa da, bölge zemininde yer yer kil tabakalarının da olduğu görülmüştür. $\mathrm{Bu}$ kil tabakalarından sondaj sırasında alınan örselenmemiş numuneler üzerinde Atterberg Limitleri, yoğunluk, su içeriği, ödometre ve konsolidasyonsuz-drenajsız (UU) üç eksenli basınç deneyleri yapılarak zemine ait indeks, sıkışabilirlik ve mukavemet parametreleri elde edilmiştir (Tablo 1).

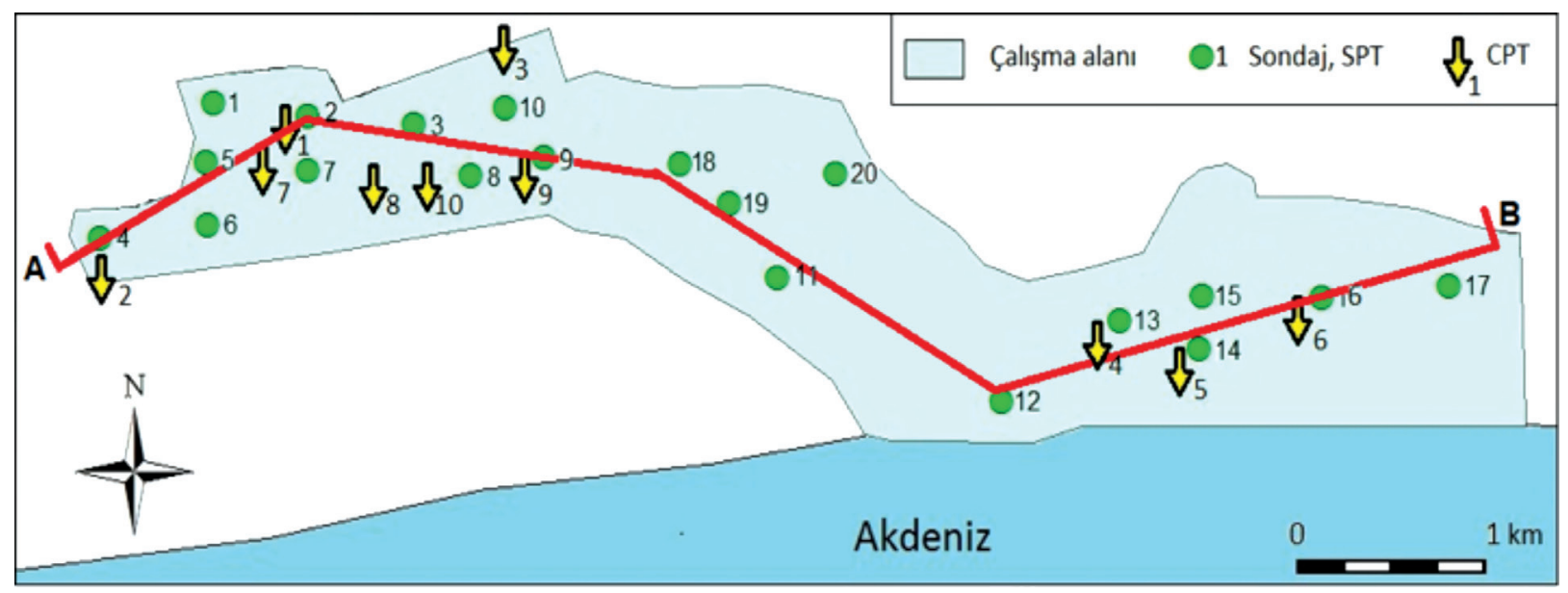

Şekil 3. Sondaj ve CPT lokasyonlarının çalışma alanındaki dağılımı.

Figure 3. Distribution of borehole and CPT locations in the study area. 
Dipova, Cangir

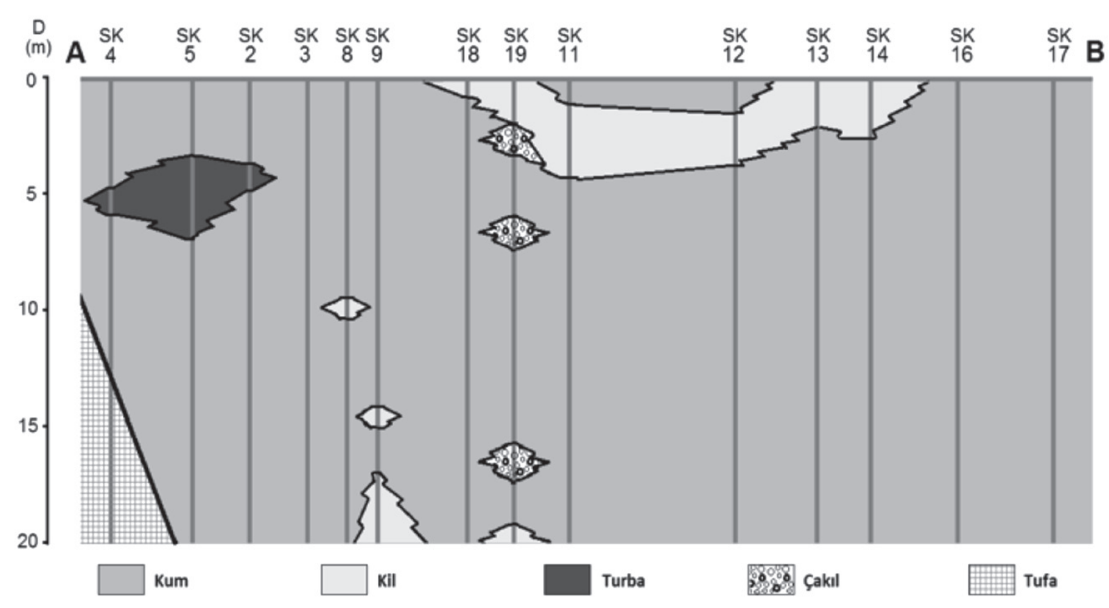

Şekil 4. A-B zemin kesiti (kesit doğrultusu Şekil 2'de gösterilmektedir).

Figure 4. A-B cross section (section line is shown in Figure 2).
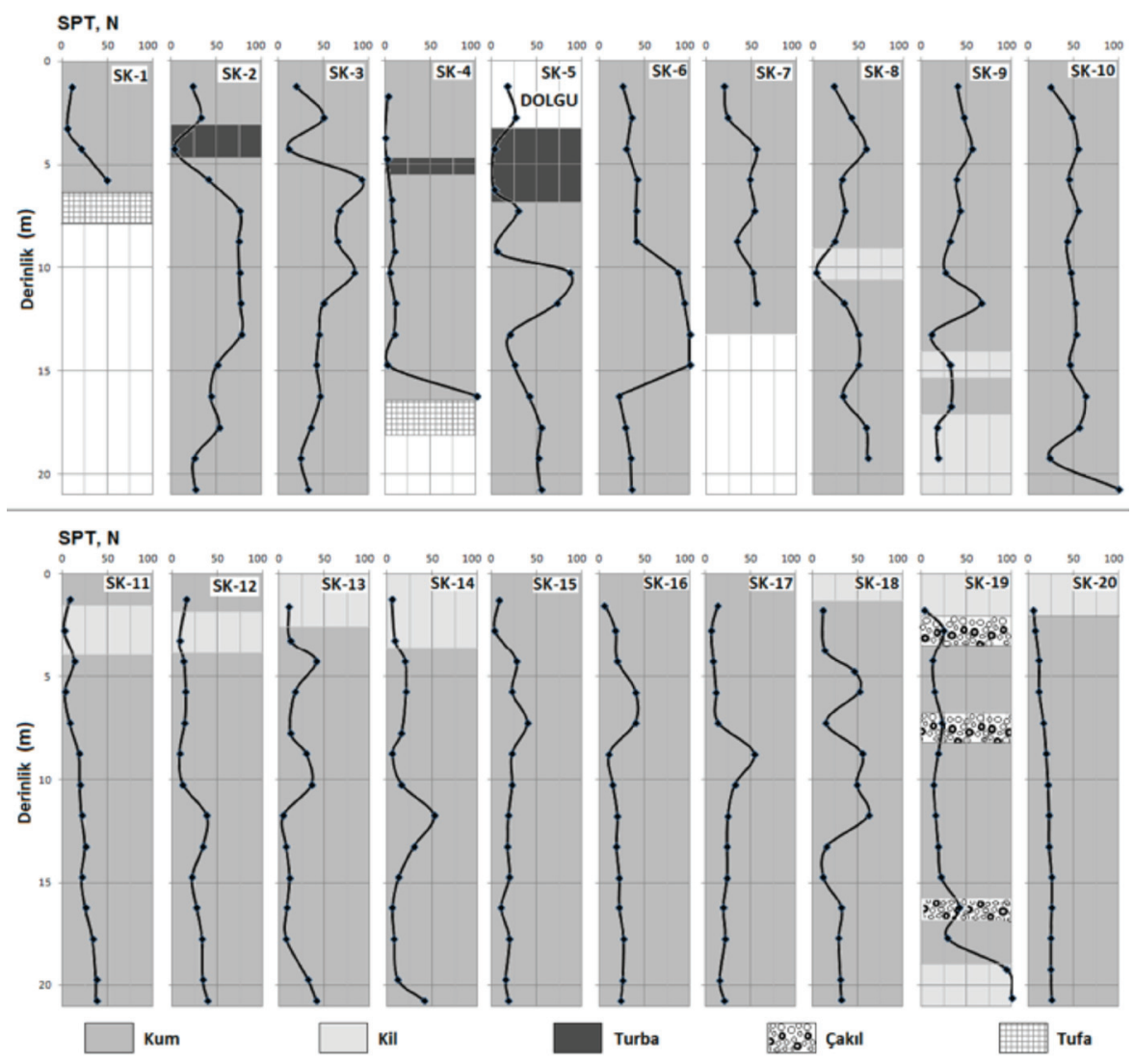

Şekil 5. SPT darbe sayısının (N) derinlikle değişimi.

Figure 5. Variation of SPT count (N) with depth. 


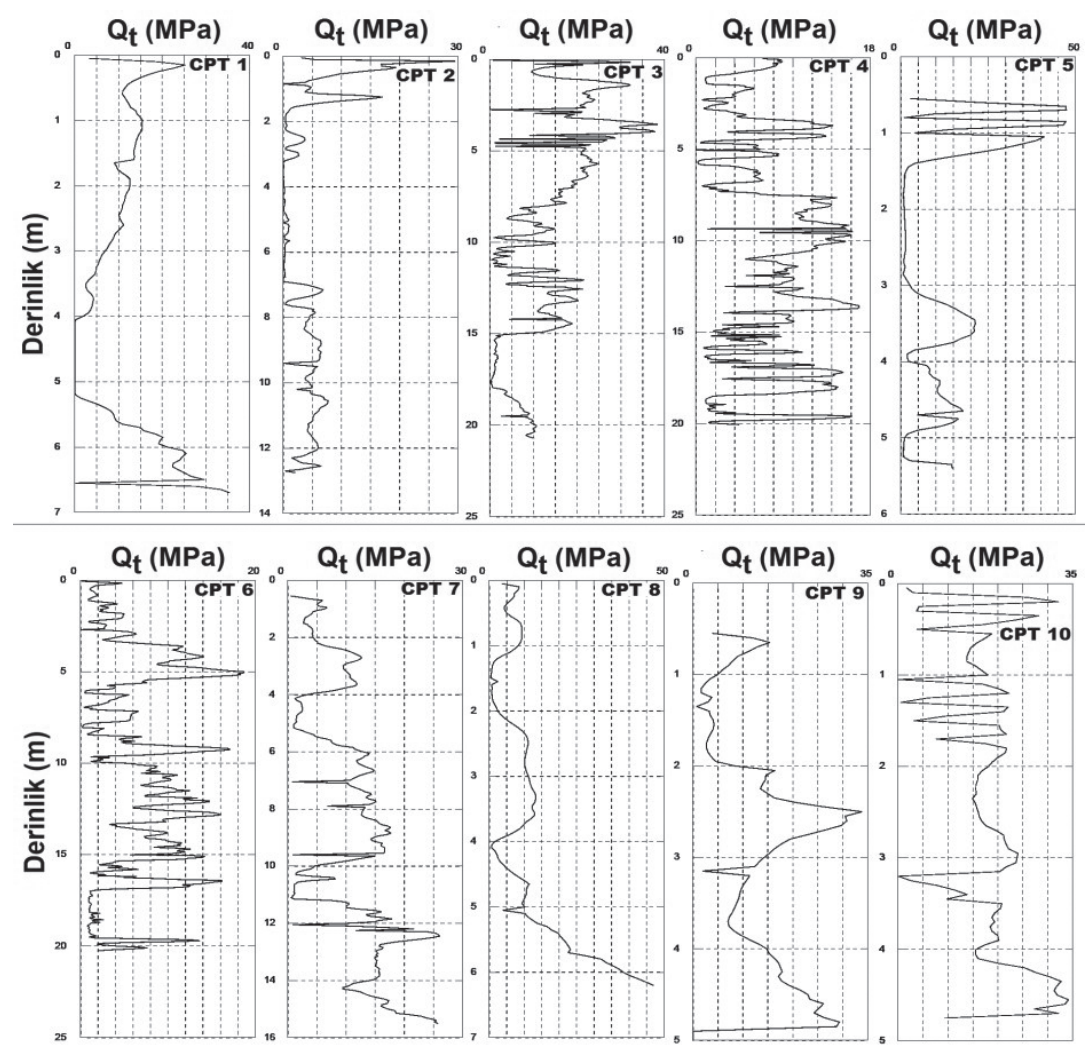

Şekil 6. CPT deneylerinde elde edilen düzeltilmiş uç direnci $\left(\mathrm{Q}_{\mathrm{t}}\right)$ değerlerinin derinlikle değişimi.

Figure 6. Variation of the corrected tip resistance $\left(Q_{t}\right)$ values obtained from CPT tests with depth.

Çizelge 1. Zeminlerin indeks, sıkışabilirlik ve dayanım parametreleri:

Table 1. Index, compressibility and strength parameters of the soils.

\begin{tabular}{lccccccccc}
\hline Sondaj & Derinlik $(\mathrm{m})$ & $\gamma\left(\mathrm{kN} / \mathrm{m}^{3}\right)$ & $\mathrm{w}_{\mathrm{n}}$ & $\mathrm{LL}$ & $\mathrm{PL}$ & $\mathrm{PI}$ & $\mathrm{c}_{\mathrm{u}}(\mathrm{kPa})$ & $\mathrm{Cc}$ & Açılama \\
\hline SK-4 & $3.00-3.50$ & 17.2 & 64 & 53 & - & - & 29 & 0.423 & Kil-Turba \\
SK-5 & $5.50-6.00$ & 10.8 & 354 & 117 & - & - & 30 & 0.637 & Turba \\
SK-9 & $16.00-16.5$ & 19.5 & 30 & 51 & 26 & 25 & 133 & 0.123 & $\mathrm{CH}$ \\
SK-9 & $19.0-19.50$ & 20.6 & 29 & 43 & 20 & 25 & 192 & 0.125 & $\mathrm{CL}$ \\
SK-12 & $2.50-3.00$ & 19.1 & 45 & 57 & 38 & 19 & 92 & 0.386 & MH \\
SK-13 & $1.00-1.50$ & 20.9 & 26 & 39 & 22 & 17 & & 0.218 & $\mathrm{CL}$ \\
SK-14 & $2.00-2.50$ & 19.2 & 36 & 41 & 21 & 20 & 36 & & $\mathrm{CL}$ \\
SK-14 & $2.50-3.00$ & 20.1 & 40 & 64 & 29 & 35 & & 0.300 & $\mathrm{CH}$ \\
SK-16 & $1.00-1.50$ & 21.5 & 24 & 47 & 23 & 24 & & 0.186 & $\mathrm{CL}$ \\
SK-19 & $1.50-2.00$ & & & 42 & 19 & 23 & & & $\mathrm{CL}$ \\
SK-19 & $17.5-18.00$ & & & 46 & 23 & 23 & & & $\mathrm{CL}$ \\
\hline
\end{tabular}


Dipova, Cangir

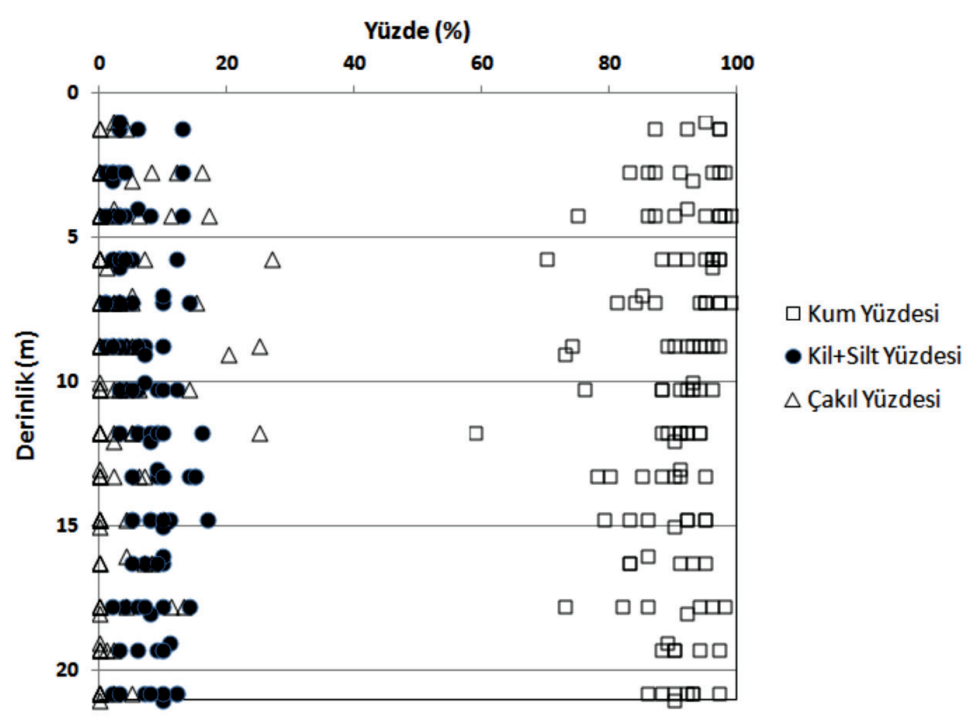

A

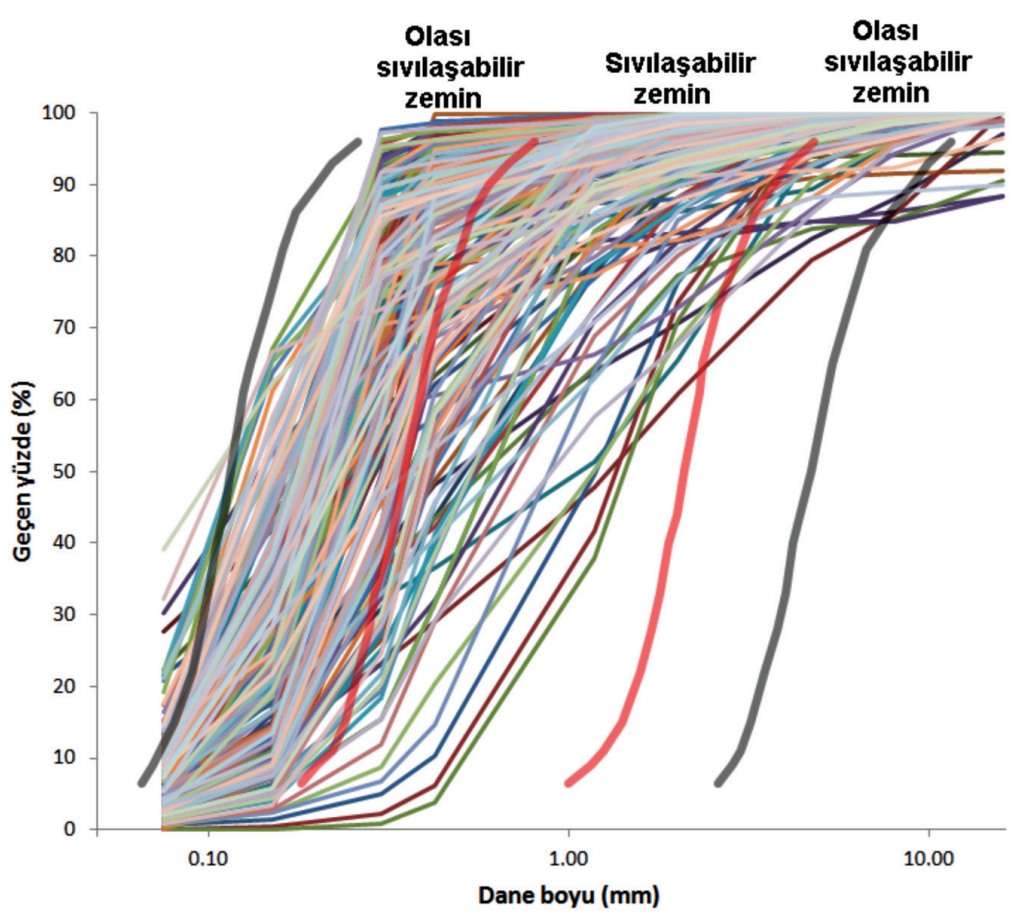

B

Şekil 7. A) Zeminlerin çakı1, kum ve ince tane yüzdelerinin derinlikle değişimi, B) Tüm örneklerin tane boyu dağ1lım eğrileri (sınırlar Tsuchida, 1970'den alınmıştır).

Figure 7. A) Variation of gravel, sand and fine grains percentage with depth B) Grain size distribution curves of all samples (borderlines are taken from Tsuchida, 1970). 


\section{SISMIIK KAYNAK KARAKTERIZASYONU}

Sismik tehlike analizinin en önemli aşamalarından birisi sismik kaynak karakterizasyonudur. $\mathrm{Bu}$ aşamada ilk olarak sismik kaynakların geometrileri belirlenir, diri fay haritası çıkartılır ve makrosismisite kataloğu derlenir. Elde edilen bu katalog verileri kullanılarak büyüklük-tekrar ilişkileri modellenir ve her fayın üretebileceği maksimum deprem büyüklüğü belirlenir. Bu çalışmada Erdik vd. (1999)'un Türkiye geneli için gerçekleştirdikleri çalışma temel alınarak Dipova ve Cangir (2011) tarafından önerilen sismik kaynak karakterizasyonu kullanılmıştır (Şekil 8). Dipova ve Cangir (2011) tarafından tanımlanan sismik kaynaklara ait büyüklük-tekrar verileri Tablo 2 'de sunulmuştur.

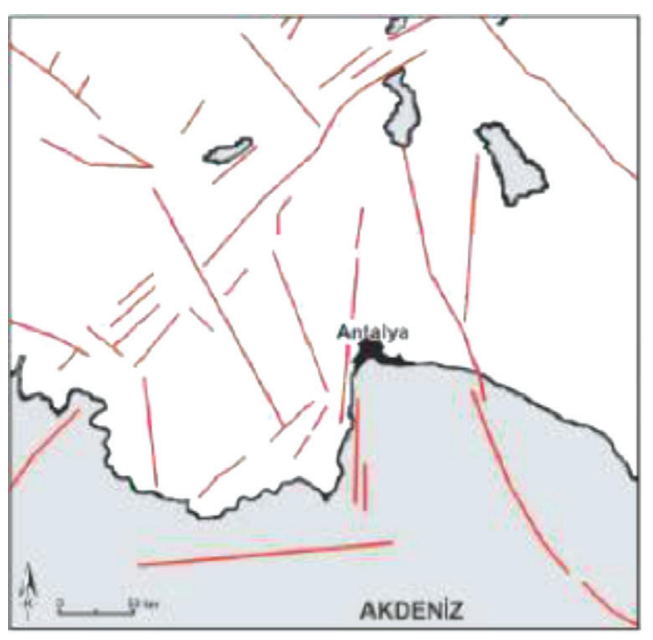

A

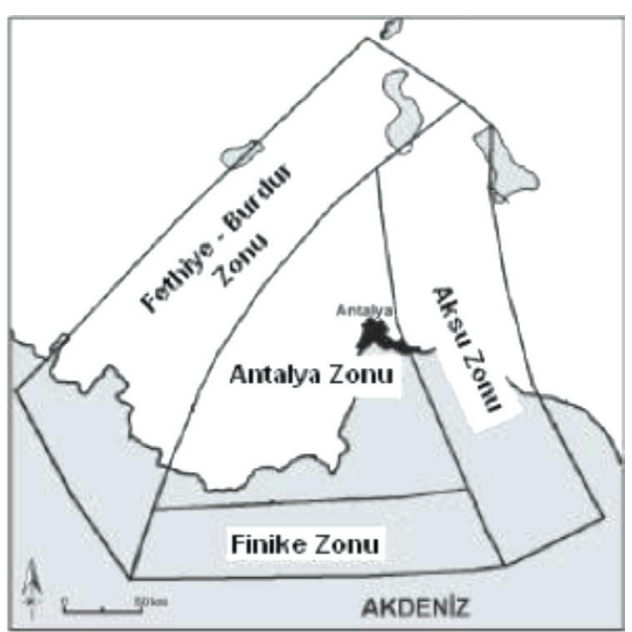

B

Şekil 8. A) Antalya yöresinde aktif ve potansiyel aktif fay zonları (Erdik vd., 1999'dan değiştirilerek), B) Çalışmada baz alınan sismotektonik bölgeler (Dipova ve Cangir, 2011).

Figure 8. B) Active and potentially active fault zones in the Antalya region (modified from Erdik et al., 1999), B) Seismotectonic regions as the basis for the study (Dipova and Cangir, 2011).

Çizelge 2. Antalya ve civarındaki sismotektonik bölgelerin a ve b parametreleri (Dipova ve Cangir, 2011).

Table 2. The a and b parameters of seismotectonics zones around Antalya (Dipova and Cangir, 2011).

\begin{tabular}{cccc}
\hline SíSMOTEKNIK BÖLGE & $\boldsymbol{a}$ & $\boldsymbol{b}$ & $\mathbf{M}_{\mathbf{w}}(\mathbf{m i n})-\mathbf{M}_{\mathbf{w}}(\mathbf{m a k s})$ \\
\hline Fethiye-Burdur & 6.65 & 0.98 & $4.0-6.7$ \\
Antalya & 6.59 & 1.06 & $4.0-5.9$ \\
Finike & 5.74 & 0.86 & $4.0-6.5$ \\
Aksu & 5.61 & 0.92 & $4.0-6.0$ \\
\hline
\end{tabular}




\section{SİSMIK TEHLİKE ANALİi̇}

Sismik tehlike analizi deterministik ve olasılıksal yöntemlerle yapılmaktadır. Deterministik yöntem en kötü yer hareketi koşulunun değerlendirilmesi için doğrusal bir yaklaşım dikkate alırken, olasılıksal yöntem depremin büyüklügüu, yeri, tekrarlanma aralığ1 ve bunlara bağlı olarak yer hareketi üzerindeki belirsizlikleri dikkate almaktadır (Kramer, 1996). Her iki yöntem de uygulama yönünden avantajlara ve dezavantajlara sahiptir. Bu sebeple, hangi modelin daha iyi sonuçlar verdiği sorusuna cevap halen aranmakta ve tartışılmaktadır (Seyrek, 2009). Her iki yöntemin de analizlere 1şık tutabilmesi için birbirlerine tamamlayıcı olmaları gerekir. Alınacak kararın önemine, sismik aktiviteye ve projenin konumuna bağl olarak bir yöntemin diğerine önceliği ortaya çıkabilecektir (McGuire, 2001).

Deterministik sismik tehlike analizi yaklaşımında önce proje sahasını etkileyebilecek deprem kaynaklarından daha önceden meydana gelmiş en büyük depremleri ortaya koymak gereklidir. Eğer deprem kayıt tarihçesi yeterince eski değil veya deprem kayıtlarında bazı eksiklikler sözkonusu ise en büyük deprem değeri, yerine göre 0.5 birim arasında arttırılabilir. İkinci aşamada ise, proje sahasının bulunduğu bölgenin karakteristiklerine en uygun azalım ilişkisi seçilir. Proje sahasına belirli bir uzaklıkta bulunan deprem kuşağındaki maksimum büyüklükteki depremin proje sahasında ana kayada oluşturacağ maksimum yer ivmesi, azalım ilişkisi yoluyla hesaplanır. Bu yaklaşımın oldukça pratik olması yanında en büyük dezavantajı proje sahasını etkileyecek maksimum yer ivmesi değerinin ortaya konulmasında rol oynayan belirsizliklerin yeterince hesaba katılamamasıdır.

Olasıl1ksal sismik tehlike analizinde(OSTA), depremin büyüklüğü, yeri ve tekrarlanma zaman aralığına bağlı olarak, belirlenen sahada yap1 tasarımı veya performans değerlendirilmesi için seçilen yıllık aşılma olasılıklarına karşılık gelen yer hareketi parametreleri hesaplanır. OSTA'nın genel aşamaları şöyle sıralanabilir; 1) proje alanında geçmişte meydana gelen deprem kayıtlarının derlenmesi ve güvenilir bir deprem kataloğunun oluşturulması, 2) ana şokların, öncü ve artçı şoklardan belirli bir zaman uzaklık penceresine göre ayrılmas1, 3) sismik kaynakların belirlenmesi, (4) oluşturulan deprem kataloğundaki depremlerin merkez üstlerinin konumuna göre sismik kaynaklara dağıtılması, belirlenen sismik kaynaklarla ilişkilendirilemeyen depremlerin katkısını da hesaba katmak üzere geri plan alan kaynakların tanımlanmas1, 5) uygun bir stokastik modelin seçilmesi, 6) bölge için bir azalım ilişkisi geliştirilmesi veya mevcut azalım ilişkilerinden uygun birinin seçilmesi, 7) bütün bu verileri kullanarak proje alanının sismik tehlikesini hesaplamak üzere hazırlanmış uygun bir bilgisayar yazılımının kullanılması (Yücemen, 2008).

Çalışma alanında olasılıksal sismik tehlike analizi yöntemi uygulanarak, kaya taban ve zemin seviyesi için $0.03^{\circ} \mathrm{x} 0.03^{\circ}$ karelaj yapılarak 475 yıllık tekerrür süresi için maksimum yatay yer ivmeleri hesaplanmıştır. Sismik tehlike analizinin yapılmasinda CRISIS2007 yazılımı (Ordaz vd., 2007) kullanılmıştır. Boore ve Atkinson (2008) azalım ilişkisi kullanılarak Antalya ili için ana kayada ve $\mathrm{V}_{\mathrm{s} 30}=200 \mathrm{~m} / \mathrm{sn}$ zemin için 475 yıllık tekerrür süresine karşılık gelen eş-ivme haritaları elde edilmiştir (Şekil 9). Buna göre $\mathrm{V}_{\mathrm{s} 30}=200$ $\mathrm{m} / \mathrm{sn}$ için hesaplanan maksimum yer ivmesi değerinin $0.31 \mathrm{~g}$ ile $0.38 \mathrm{~g}$ arasında, ana kaya $\left(\mathrm{V}_{\mathrm{s} 30}=1000 \mathrm{~m} / \mathrm{sn}\right)$ için ise bu değerin $0.11 \mathrm{~g}$ ile $0.18 \mathrm{~g}$ arasında değişim gösterdiği belirlenmiştir. Daha sonra, Boore ve Atkinson (2008) azalım ilişkisi kullanılarak yapılan deterministik tehlike 
analizi ile 475 y1llık tekerrür süresine karşılık gelen ivme değeri, Lara bölgesinde $\mathrm{V}_{\mathrm{s} 30}=200 \mathrm{~m} /$ sn için hesaplanmıştır. Buna göre $\mathrm{V}_{\mathrm{s} 30}=200 \mathrm{~m} /$ sn için hesaplanan en büyük yer ivmesi $0.46 \mathrm{~g}$ olarak bulunmuştur. Deterministik ve olasıl1ksal yöntemler kullanılarak, elde edilen bu sonuçlara göre bölgede $\mathrm{V}_{\mathrm{s} 30}=200 \mathrm{~m} / \mathrm{sn}$ olan zeminler için yapılacak olan sıvılaşma hesaplarında $\mathrm{a}_{\max }=0.4 \mathrm{~g}$ olarak alınmasının uygun olacağ düşünülmüsştür.

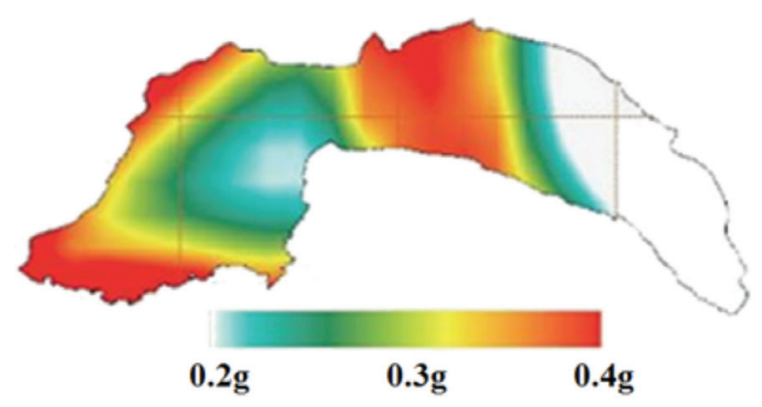

(a)

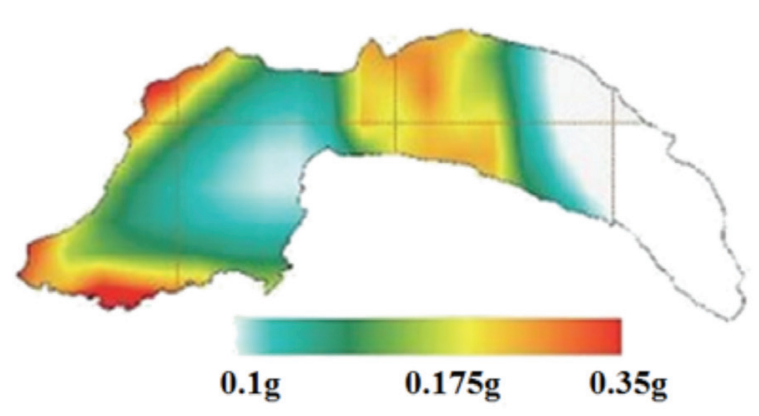

(b)

Şekil 9. Boore ve Atkinson (2008) bağıntısına göre 475 yıllık tekerrür süresine karşılık gelen eş-ivme haritası; A) $\left.\mathrm{V}_{\mathrm{s} 30}=200 \mathrm{~m} / \mathrm{sn}, \mathrm{B}\right)$ Kayada.

Figure 9. Iso-acceleration map corresponding to 475 years return period, according to Boore and Atkinson (2008); A) $V_{s 30}=200 \mathrm{~m} / \mathrm{s}$, B) in rock.

\section{SIVILAŞMA}

Literatürde, sismik faaliyetleri yüksek bölgelerde yer alan gevşek kum/siltli kum zemin tabakalarının sıvılaşabilirliğini belirlemekte kullanılan değişik yöntemler bulunmaktadır. Sıvilaşma potansiyelinin belirlenmesinde en yaygın şekilde kullanılan yöntem Seed ve Idriss (1971) tarafından geliştirilen yöntem olup, zemin katmanının sıvılaşmaya karş1 emniyet katsayıs1 (Kayma dayanımı/Kayma gerilmesi) şeklinde belirlenmektedir. 1960'l1 ve 1970'li y1llarda H. B. Seed ve arkadaşları tarafından Kaliforniya Üniversitesi'nde yapılan çalışmalar, sıvılaşma olayının anlaşılmasında büyük rol oynamıştır. Bu çalışmalar genellikle sıvılaşmayı tetikleyen yükleme koşullarının ortaya konmasına dönük çalışmalardır. Kum kaynaması, yüzey çatlakları veya yanal yayılma görülen zeminlerde sıvılaşmanın oluştuğu kabul edilerek toplanan veriler, çoğunlukla düz yüzeyli ve sığ derinliklerdeki alüvyon ve nehir çökellerinden alınmıştır. Seed ve Idriss yöntemi zeminlerin sıvılaşma dirençlerinin belirlenmesi için iki değişkenin hesaplanmasını veya tahmin edilmesini gerektirir.

i. Zemin tabakasındaki sismik gerilmeyi ifade eden devirsel gerilme oran1, CSR (Cyclic Stres Ratio)

ii. Zeminin sıvılaşmaya karşı direncini gösteren devirsel direnç oranı, CRR (Cyclic Resistant Ratio)

Bir zeminin sıvılaşabilirliğinin göstergesi olan sıvılaşmaya karsı güvenlik katsayısı (FL), aşağıdaki eşitlikten hesaplanır.

$\mathrm{FL}=\left(\mathrm{CRR}_{7,5} / \mathrm{CSR}\right) \times \mathrm{MSF}$

$\mathrm{CRR}_{7.5}: 7.5$ büyüklüğündeki bir deprem için CRR

CSR : Depremin neden olduğu tekrarlı gerilme oran1

MSF : Deprem büyüklüğü için önerilen ölçek faktörüdür.

Kuramsal olarak; sıvılaşmaya karsı güvenlik katsayısının 1'den küçük ve eşit değerleri için 
sıvılaşmanın meydana geleceği, 1'den büyük değerleri için sıvılaşmanın olmayacağı kabul edilir (Seed ve Idriss, 1982). Sıvılaşmaya karşı güvenlik katsayısı, belli bir derinlikteki bir zemin seviyesinin sıvılaşma direncinin, bir başka deyişle ilgili zemin seviyesinin sıvılaşabilirliliğinin göstergesidir. Herhangi bir noktada sıvılaşmanın olup olmayacağının bilinmesi ya da sıvılaşma olasılığının hesaplanması, araştırılan bölgedeki hasarın tahmin edilmesi için yeterli değildir. Sadece güvenlik faktörünün hesaplanması, geniş ve derin alanlar için göreceli bir değerlendirme yapılmasına ve sıvılaşma potansiyeli açısından sıvılaşma haritalarının hazırlanmasına doğrudan imkân vermemektedir. Sıvılaşma olasılı̆̆ı bulunan bir zeminde sıvılaşma şiddet indeksinin değer aralığının ne olacağı büyük önem kazanmaktadır. $\mathrm{Bu}$ durum göz önünde bulundurularak, Iwasaki vd. (1982) tarafindan güvenlik faktörünü de içerecek şekilde "sıvılaşma indeksi (IL)" adı verilen bir parametre önerilmiş ve bu indeksin hesaplanması için aşağıdaki eşitlik (Eşitlik 2) verilmiştir.

$\mathrm{IL}=020 \mathrm{FzWzdz}$

$\mathrm{FL}<1.0$ için $\mathrm{F}(\mathrm{z})=1-\mathrm{FL}$

$\mathrm{FL} \geq 1.0$ için $\mathrm{F}(\mathrm{z})=0$

$\mathrm{z}<20 \mathrm{~m}$ için $\mathrm{W}(\mathrm{z})=10-0.5 \mathrm{z}$

$\mathrm{z} \geq 20 \mathrm{~m}$ için $\mathrm{W}(\mathrm{z})=0$

z: Yüzeyden zemin tabakasının orta noktasına olan derinlik $(\mathrm{m})$
Sıvılaşmayakarşı güvenlik katsayısının(FL), sıvılaşmanın gelişmeyeceği sınır değeri üzerinde bir mutabakat olmaması, analizlerde kullanılan deprem ve zemin parametrelerinin içerdikleri belirsizlikler, sıvılaşma açısından olasılığa dayalı bir değerlendirmenin yapılmasına ihtiyacı ortaya çıkarmıştır. Bazı araştırmacılar (Chen ve Juang, 2000; Juang vd., 2003; Çetin vd., 2004) sıvılaşmanın olasılık esaslı değerlendirilmesine yönelik çalışmalar yapmıştır.

Çalışma alanındaki suya doygun kum katmanlarının sıvılaşma davranışının araştırılması amacıyla olasılıksal sıvılaşma potansiyeli $\left(\mathrm{P}_{\mathrm{L}}\right)$ ve Iwasaki vd. (1982) tarafindan geliştirilen, Yılmaz ve Çetin (2004) tarafından revize edilen "sıvılaşma şiddeti indeksi" (LSI) analizi gerçekleştirilmiştir. Bu yaklaşıma göre (LSI); sıvılaşma olasılı̆̆ (PL), potansiyel olarak sıvılaşabilir tabaka kalınlığ $1(\mathrm{TH})$ ve potansiyel olarak sıvılaşabilir tabakaya olan derinliğin (WF) bir fonksiyonudur (Eşitlik 3).

$L S 1=\Sigma_{\mathrm{i} 1}^{\mathrm{n}}$ PL.TH.WF

Burada:

$\mathrm{P}_{\mathrm{L}}=$ Sıvılaşma olasılı̆̆ ${ }_{1}$ (ondalık sayı olarak)

$\mathrm{TH}=$ potansiyel olarak sıvılaşabilir tabaka kalınlığ 1

$\mathrm{WF}=1-0.05 . \mathrm{z} \quad(\mathrm{z}<20 \mathrm{~m}, \mathrm{z}$ : yüzeyden metre cinsinden derinliği ifade eder).

Sıvılaşma olasılığı (PL) Çetin vd. (2004) tarafından Eşitlik 4'teki gibi tanımlanmaktadır.

$$
P_{L}=\Phi\left(-\frac{\left(N_{1,60} \cdot(1+0.004 \cdot F C)-13.32 \cdot \ln (C S R)-29.53 \cdot \ln \left(M_{w}\right)-3.70 \cdot \ln \left(\sigma_{v}^{\prime}\right)+0.05 \cdot F C+44.97\right)}{2.70}\right)
$$


Burada:

$\mathrm{N}_{1,60}$ : Düzeltilmiş SPT darbe sayısı

FC: İnce tane oranı

CSR: Devirsel kayma gerilmesi oranı

$\mathrm{M}_{\mathrm{w}}$ : Deprem moment büyüklüğü

$\mathrm{s}_{\mathrm{v}}$ ': Efektif gerilme

$\Phi$ : Standart kümülatif normal dağılım $\left(\Phi^{-1}{ }_{(\mathrm{PL})}\right.$ standart kümülatif normal dağılımın tersini ifade etmektedir.)

Tüm SPT, N değerleri düşey gerilme durumları için düzeltilmiş ve Liao ve Whitman (1986) CN değerleri ile çarpılarak, 1 atm'lik efektif düşey gerilme altında ölçüleceği varsayılan N1 değerine çevrilmiştir. Bir sonraki aşamada ise farkl1 enerji, ekipman ve prosedür uygulamaları için Eşitlik 5'te özetlendiği şekilde düzeltilerek, $\mathrm{N}_{1,60}$ değerleri elde edilmiştir

$\mathrm{N}_{1,60}=\mathrm{N} 1 \cdot \mathrm{CR} \cdot \mathrm{CS} \cdot \mathrm{CB} \cdot \mathrm{CE}$

Burada:

CR: Tij uzunluğu düzeltmesi (Skempton, 1986)

CS: Numune alıcı düzeltmesi (Skempton, 1986)

CB: Delgi çap1 düzeltmesi (Skempton, 1986)

CE: Tokmak enerji verim düzeltmesi (Clayton vd., 1995)

LSI indeksi sınırları aşağıdaki gibi ifade edilmektedir (Yılmaz ve Çetin, 2004).

- $0<\mathrm{LSI}<0.35$ sıvılaşma potansiyeli çok düşük

- $0.35<$ LSI $<1.30$ sıvılaşma potansiyeli düşük

$\bullet 1.30<$ LSI $<2.5$ sıvılaşma potansiyeli yüksek

- LSI $>2.5$ sıvılaşma potansiyeli çok yüksek
Temiz kumlar dışında ince taneli zeminlerin de bazı koşullarda sıvılaşabileceği bilinmektedir. Önalp ve Arel (2002)'nin Adapazarı Kriterine göre; siltlerde kesin sıvılaşma belirmesi için; siltlerin, düşük plastisiteli silt (ML) sınıfinda olması, numunelerin doğal su muhtevasının (w) likit limite $\left(\mathrm{w}_{\mathrm{L}}\right)$ eşit olması, $\mathrm{w}_{\mathrm{L}}$ değerinin \%30'dan küçük olması ve zeminin içerdiği kil danelerin \%15'ten az olması durumunun aynı anda oluşması gerekmektedir (Önalp ve Arel, 2002). Çalışma alanındaki ince daneli zeminler bu özellikleri taşımadı̆̆ından, sıvılaşma analizleri sadece suya doygun kum katmanları için uygulanmıştır.

\section{COĞRAFİ BİLGİ SİSTEMLERİ (CBS) ÇALIŞMALARI}

Mühendislik veri üretimi ve analizi sonrasında, coğrafi bilgi sistemleri (CBS) yardımı ile elde edilen tematik haritalar bu verilerin kolay ve anlaşılır bir biçimde sunulmasına olanak sağlamaktadır. $\mathrm{Bu}$ amaçla, çalışma alanına ait çeşitli tematik haritalar, CBS kullanılarak bilgisayara ortamına aktarılmıştır. Öncelikle bölgenin 1/25000 ölçekli topoğrafik haritas1 sayısallaştırılmıştır. Yerleşim alanının 1/5000 ölçekli imar paftaları da ArcInfo programları kullanılarak sayısallaştırılmıştır. Arazide yapılan mekanik sondajlar ve CPT deney noktaları da CBS ortamına aktarılarak lokasyon haritası hazırlanmıştır. Çalışmada sıvılaşma şiddet indeksi haritas1 ArcGIS r.9.3 (ESRI, 2009) programında Kriging interpolasyon yöntemi kullanılarak hazırlanmıştır. İnterpolasyon yöntemleri, bilinen değerlerden bilinmeyen değerler türetmeye (başka bir deyişle ara değer bulmaya) yarayan sayısal yöntemlerdir. İnterpolasyonla üretilen haritalarda sondaj sıklığ 1 ve sahaya yayılımının belirsizlikler üzerinde etkili olduğu bilinmektedir. $\mathrm{Bu}$ nedenle LSI 
haritasının sondajlardan uzaklaşan bölgelerinde kısmen bazı belirsizlikler içerebileceği hesaba katılmalıdır.

Arazideki bir inceleme noktasındaki tüm katmanlar için belirlenen olasılıksal sıvılaşma potansiyeli değerleri kullanılarak sıvılaşma şiddeti indeksi değerleri elde edilmiş ve CBS ortamında oluşturulan zemin sıvılaşma şiddeti indeksi (LSI) haritası Şekil 10'da sunulmuştur. Buna göre; çalışma alanının \% 41'lik kısmında sıvılaşma şiddeti çok yüksek, \% 27'lik kısmında yüksek, \% 19'luk kısmında düşük, \% 13'lük kısmında da çok düşük çıkmıştır. Arazinin doğu ve denize yakın bölümlerinin sıvılaşma şiddetinin batı ve kara tarafındaki zeminlere göre sıvılaşma şiddetinin daha yüksek olduğu görülmüştür.

\section{SONUÇLAR}

Çalışmalar sonucunda; arazi geneli için sıkı kumun egemen olduğu, bazı bölümlerde ise gevşek kum, kil ve turba bulunduğu belirlenmiştir. Kumda SPT-N değerleri 0-5 m arasında 15 ile 30, 5-10 $\mathrm{m}$ arasında ise 20 ile 40 aralığındadır. Killi zeminlerde sıkışma İndisi $(\mathrm{Cc})$ değerinin 0.1230.386 arasında, drenajsız kayma dayanımının $\mathrm{c}_{\mathrm{u}}$ $=36-192 \mathrm{kN} / \mathrm{m}^{2}$ arasında olduğu bulunmuştur. Turbanın sıkışma indisi (Cc) değerleri 0.4230.637 arasındadır.

(Boore ve Atkinson) 2008 azalım ilişkisi kullanılarak zemin profili $\mathrm{V}_{\mathrm{s} 30}=200 \mathrm{~m} / \mathrm{sn}$ için yapılan olasılıksal ve deterministik sismik tehlike analizlerine göre, 475 yıllık tekerrür süresine karşıllk gelen maksimum yer ivmesi değerinin Antalya Lara-Kundu bölgesinde $0.40 \mathrm{~g}$ olarak alınmasının uygun olacağı düşünülmüştür. Fay hatlarının geometrilerindeki belirsizlikten dolay1 yapılan analizlerde alan kaynak kullanılarak bölgede oluşabilecek maksimum yer ivmesi değerleri belirlenmiştir.

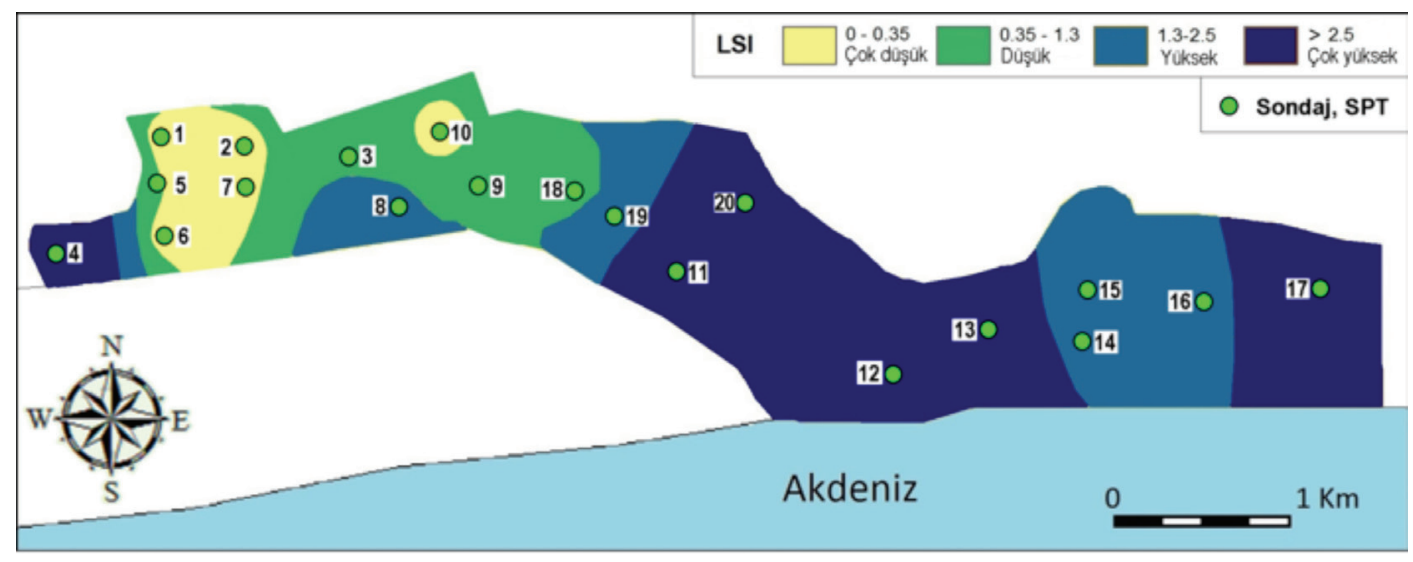

Şekil 10. Çalışma alanı için LSI indeksi dağılım haritası.

Figure 10. LSI index distribution map for the study area. 
Elde edilen tüm veriler 1şığında coğrafi bilgi sistemleri (CBS) yöntemi kullanılarak zemin sıvılaşma şiddeti indeksi (LSI) haritası oluşturulmuştur. SPT sonuçları kullanılarak hazırlanan LSI haritasına göre çalışma alanının \% 41'lik kısmında sıvılaşma şiddeti çok yüksek, \% 27'lik kısmında yüksek, \% 19'luk kısmında düşük, \% 13'lük kısmında da çok düşük çıkmıştır. Arazinin doğu ve denize yakın bölümlerinin sıvılaşma şiddetinin batı ve kara tarafındaki zeminlere göre sıvılaşma şiddetinin daha yükssek olduğu görülmüştür.

\section{KAYNAKLAR}

Acar, M. H., Budak, G., 2004. Antalya Yamansaz Bölgesi'nin sıvılaşma potansiyelinin araştırılması. Zemin Mekaniği ve Temel Mühendisliği Onuncu Ulusal Kongresi. 469, İstanbul.

Akay, E., Uysal, Ş., Poisson, A., Cravatte, J., Müller, C., 1985. Antalya Neojen havzasının stratigrafisi. T.J.K. Bülteni, 28 (2), 105-121.

Bommer, J., Spence, R., Erdik, M., Tabuchi, S., Aydınoğlu, N., Booth, E., Del Re, D., Peterken, O., 2002. Development of an earthquake loss model for Turkish catastrophe insurance. Journal of Seismology, 6, 431-446.

Boore, D. M., Atkinson, G. M., 2008. Ground motion prediction equations for the average horizontail component of PGA, PGV and 5\% damped PSA at spectral periods between $0.01 \mathrm{~s}$ and $10.0 \mathrm{~s}$. Earthquake Spectra, 24 (1), 99-138.

Çetin, K. O., Seed, R.B., Der Kiureghian, A., Tokimatsu, K., Harder, L. F., Kayen, R. E., Moss, R. E. S., 2004. Standard penetration test-based probabilistic and deterministic assessment of seismic soil liquefaction potential, Journal of Geotechnical and Geoenvironmental Engineering. ASCE, 130 (12), 1314-1340.

Chen, C. J., Juang, C. H., 2000. Calibration of SPTand CPT-based liquefaction evaluation methods, In: Innovations and applications in geotechnical site characterization, edited by: Mayne, P.W.,
Hryciw, R., Vol. 97. Geotechnical Special Publication, ASCE, Reston, 49-64.

Clayton C. R. I., Mathews M. C., Simons N. E., 1995. Site investigation. $2^{\text {nd }}$ edition, Blackwell Science.

Das, Braja M., 1983. Fundamentals of soil dynamics. Elver Science Publishers Co., Inc, New York, NY, 1983.

Deniz, A., Yücemen, M. S., 2005. Antalya yöresi için deprem tehlikesinin stokastik yöntemler ile tahmini. Antalya Yöresinin İnşaat Mühendisliği Sorunlar1 Kongresi, 22-25 Eylül 2005, Antalya.

Dipova, N., 2002. Antalya kıyı düzlüklerinin oluşumu ve mühendislik özellikleri, IV. Kıyı. IV. Kıyı Mühendisliği Ulusal Sempozyumu, 24-27 Ekim 2002, Antalya, Bildiriler Kitab1, 429-442.

Dipova, N., Cangir, B., 2011. Antalya ili yerleşim alanının depremselliğinin araştırılması. Jeoloji Mühendisliği Dergisi, 35 (2), 93-114.

Dipova, N., Oğuz, C., 1998. Lara (Antalya) kumulları ve kıyı alanı. Türkiye'nin Kıyı ve Deniz Alanları II. Ulusal Konferans1 Bildiriler Kitabı, 22-25 Eylül, ODTÜ, Ankara.

Erdik, M., Alpay Biro, Y., Onur, T., Şeşetyan, K., Birgören., 1999. Assessment of earthquake hazard in Turkey and neighboring regions. Annali Di Geofisica, 42 (6), 1125-1138.

ESRI, 2009. ArcGIS Desktop: release 9.3. Environmental Systems Research Institute, Redlands CA, USA.

Iwasaki T, K., Tokida K. Tatsuoka, Watanabe, S., Yasuda, S., Sato, H., 1982. Microzonation for soil liquefaction potential using simplified methods. Proceedings of the $13^{\text {th }}$ International Conf. on Microzonation", Seattle, USA, 3, 13191330.

Juang, C. H., Yuan, H., Lee, D. H., Lin, P. S., 2003. Simplified CPT-based method for evaluating liquefaction potential of soils. Journal of Geotechnical and Geoenvironmental Engineering, ASCE 129 (I), 66-80.

Kramer, S. L., 1996. Geotechnical earthquake engineering. Prentice Hall, New Jersey.

Liao, S. S. C., Whitman, R. V., 1986. Overburden correction factor for SPT in sand. Journal of 
Dipova, Cangir

Geotechnical Engineering, ASCE, 112 (3), 37337.

McGuire, R. K., 2001. Deterministic vs. probabilistic earthquake hazards and risks. Soil Dynamics and Earthquake Engineering, 21, 377-384.

Ordaz, M., Aguilar, A., Arboleda, J., 2007. CRISIS2007, Ver. 7.2, Program for Computing Seismic Hazard, Instituto de Ingeniería, UNAM, Mexico.

Önalp, A., Arel, E., 2002. Siltlerin sıvılaşma yeteneği: Adapazarı kriteri. Zemin Mekaniği ve Temel Mühendisliği Dokuzuncu Ulusal Kongresi, 1, 363-372, Anadolu Üniversitesi, Eskişehir.

Seed, H. B., Idriss. I. M., 1971. Simplified procedure for evaluating soil liquefaction potential. Journal of Soil Mechanics and Foundations Division, ASCE, 97 (SM9), 1249-1273.

Seed, H. B., Idriss. I. M., 1982. Ground motions and soil liquefaction during earthquakes. Earthquake Engineering Research Institute, Berkeley, CA, $134 \mathrm{p}$.

Seyrek, E., 2009. Baraj yeri sismik tehlike analizlerinde sayısal çözümleme modelleri ve bir uygulama. Eskişehir Osmangazi Üniversitesi
Fen Bilimleri Enstitüsü, Eskişehir, Doktora Tezi, $184 \mathrm{~s}$ (yayımlanmamış).

Skempton, A.W., 1986. Standard penetration test procedures and the effects in sands of overburden pressure, relative density, particle size, aging and overconsolidation. Geotechnique, 36 (3), 425447.

Tsuchida, H., 1970. Prediction and countermeasure against the liquefaction in sand deposits. Abstract of the Seminar in the Port and Harbor Research Institute, Japan.

Yılmaz, Z., Çetin, K. Ö., 2004. GIS-based seismic soil liquefaction assessment for Sakarya city after 1999 Kocaeli-Turkey earthquake. Proc. of the $11^{\text {th }}$ Int. Conf. on Soil Dynamics and Earthquake Engineering and The $3^{\text {rd }}$ Int. Conf. on Earthquake Geotechnical Engineering, 7th9th January 2004, University of California, Berkeley, USA, 909-916.

Yücemen, M. S., 2008. Deprem tehlikesinin tahmininde olasılıksal yöntemler, Bölüm: Binalar için deprem mühendisliği temel ilkeleri. Editörler, E. Canbay v.d., Bizim Büro Basımevi, 365-413, Ankara. 